\title{
GROWTH RATE AND THERMAL TOLERANCE OF TWO ENDANGERED SNAKE RIVER SNAILS
}

\author{
Steven Lysne ${ }^{1,2}$ and Peter Koetsier ${ }^{1}$
}

\begin{abstract}
AвSTRACT.-We investigated the temperature tolerance and growth of 2 federally protected freshwater gastropods from southern Idaho: Valvata utahensis and Pyrgulopsis idahoensis. Snails were collected in the Snake River and transported to the laboratory where they were kept under highly controlled conditions. In varying-temperature, short-duration experiments, the temperatures tolerated by both species were between $7^{\circ} \mathrm{C}$ and $34^{\circ} \mathrm{C}$. In constant-temperature, longduration experiments, growth rates were between $0.004 \mathrm{~mm} \cdot \mathrm{d}^{-1}$ and $0.016 \mathrm{~mm} \cdot \mathrm{d}^{-1}$, and we created growth curves for both species that were previously lacking. Our results are among the first to report temperature tolerances and growth rates of native Snake River snails, and we discuss implications for the biology and management of both species.
\end{abstract}

Key words: endangered species, Valvata, Pyrgulopsis, temperature.

The Snake River of southern Idaho contains a rich gastropod fauna (Frest and Bowler 1993), but the river is severely impacted by anthropogenic sources (USEPA 2002). Several western North American gastropod species are federally protected from the risk of extinction primarily attributed to habitat modification (Frest 2002). Two gastropod species, the Utah Valvata (Valvata utahensis, Call 1884) and the Idaho springsnail (Pyrgulopsis idahoensis, Pilsbry 1933), are among the 5 listed as threatened or endangered by the United States Fish and Wildlife Service in 1992 (USFR 1992). In a recent review $P$. idahoensis was synonymized with the conspecific P. robusta, Walker 1908 (Hershler and Liu 2004). We maintain the use of $P$. idahoensis for consistency in our worksin-progress but encourage interested readers to consider Hershler and Liu (2004). Both snails are native to the Snake River of southern Idaho and are believed to have experienced significant declines in distribution as a result of river regulation for irrigation and hydroelectric power production and associated declines in water quality. Both species are believed to require clean, cool water, and the increased temperatures and sedimentation present in reservoirs is thought to be detrimental to their growth, reproduction, and survival (USFWS 1995). Effects of river regulation are not specifically addressed here. It is well known, however, that stage level fluctuations below large dams dewater invertebrate habitat, alter the geomorphology of the streambed, disrupt natural processes, expose invertebrates to ambient air temperatures, and result in significant mortality of invertebrates due to desiccation and predation (Brusven 1984, Bovee 1985, Christman et al. 1996, Poff et al. 1997, Pringle et al. 2000, Watters 2000).

Unfortunately biologists lack information regarding the basic life history and environmental requirements of these snail species, making management for conservation and recovery difficult. Water temperature, for example, is an environmental attribute which can affect many aspects of an organism's life history (McMahon 1990, Bevelhimer 1996, Claxton et al. 1999, Voss et al. 2001). Indeed, stream temperature may be the most important physical factor influencing the distribution and abundance of stream invertebrates (Harman 1974, Ward and Stanford 1979). Temperature can raise metabolic rates, thereby speeding physiological processes; affect the behavior of an animal, dictating where and when it feeds, rests, or attempts reproduction; and profoundly influence the distribution of species in aquatic ecosystems (Michelson 1961, Winterbourne 1969, Quinn et al. 1994, Schrag et al. 1994, Allan 1995, Albrecht et al. 1999).

The effect of temperature on life histories of snails has been the focus of intense study in the past (Winterbourne 1970, Costil 1994, 
Schrag et al. 1994, Strzelec 1999, Richards et al. 2001); yet, little information exists specific to the importance of temperature to native Snake River snails. Our objective was to examine how water temperature influences activity and growth in these 2 species. Our null hypothesis was that growth across temperature treatments would not differ. Based on past reports (USFR 1992), we predicted that (1) highest growth rates would be realized in the middle of a continuum of temperatures maintained in the laboratory and (2) those temperatures resulting in highest growth would be relatively cool. Our predictions imply that growth rates will be attenuated at both higher and lower temperatures, thus approximating a bell-shaped curve. We tested no hypotheses and made no predictions regarding the thermal activity range of snails.

\section{Methods}

Snails were collected from 2 large reservoirs on the main stem of the Snake River in south central Idaho. Approximately 250 Valvata utahensis were collected in June and August 2001, and in April and June 2002 from Lake Walcott Reservoir $\left(42^{\circ} 40^{\prime} 20^{\prime \prime} \mathrm{N}, 113^{\circ} 27^{\prime} 39^{\prime \prime} \mathrm{W}\right.$ [2001]; $42^{\circ} 40^{\prime} 22^{\prime \prime} \mathrm{N}, 113^{\circ} 25^{\prime} 55^{\prime \prime} \mathrm{W}$ [2002]). Lake Walcott is part of the Minnidoka National Wildlife Refuge and is managed for fish and wildlife. As a result, the water level does not vary substantially from the surface elevation of $1278 \mathrm{~m}$ at full pool. Lake Walcott is approximately $53 \mathrm{~km}$ long, covers approximately $4796 \mathrm{ha}$, and has a mean annual discharge of $240.7 \mathrm{~m}^{3} \cdot \mathrm{s}^{-1}$. Valvata utahensis is generally found at water depths of 2-8 m (USGS 2000) and individuals were collected in Lake Walcott on fine substrates with mean particle sizes $\leq 0.04 \mathrm{~mm}$ in diameter (USBOR 2002).

Approximately 120 Pyrgulopsis idahoensis were collected in June and July 2001, and in May and June 2002 from C.J. Strike Reservoir $\left(42^{\circ} 54^{\prime} 45^{\prime \prime} \mathrm{N}, 115^{\circ} 53^{\prime} 16^{\prime \prime} \mathrm{W}\right.$ [2001, 2002]). C.J. Strike Reservoir is approximately $56 \mathrm{~km}$ long, covers approximately $3076 \mathrm{ha}$, and has a mean annual discharge of $49.1 \mathrm{~m}^{3} \cdot \mathrm{s}^{-1}$. C.J. Strike Reservoir is managed primarily for storage of irrigation water and hydroelectric power generation. Therefore, the surface elevation of $748 \mathrm{~m}$ at full pool can fluctuate daily and seasonally. For purposes of power generation, C.J. Strike is operated in a load-following capacity whereby water is released during times of peak energy demand resulting in dramatic stage level fluctuations immediately below the dam in the main stem of the Snake River. Substrates at collection sites were primarily coarse sand $(0.2-2 \mathrm{~mm})$ to small pebble-sized particles $(1.6-3.2 \mathrm{~cm})$.

We collected snails from random locations within a known colony in both Lake Walcott and C.J. Strike Reservoirs with SCUBA-trained biologists from the U.S. Bureau of Reclamation. The reservoir sites utilized were the only ones available for collections due to U.S. Bureau of Reclamation permitting terms and conditions. Snails were suctioned to the lake surface and captured in a 500- $\mu$ m-mesh sieve. Field collections were sorted, placed in polyethylene collection jars, and transported on ice to the laboratory. Snails were kept in four 18-L aquaria in an environmentally controlled greenhouse facility. Each aquarium was filled with sterilized substrates, deionized water spiked with $1 \mathrm{~L}$ of Snake River water (to promote the growth of the native aquatic flora), and aerated. Aquaria remained at $19^{\circ} \mathrm{C} \pm 2{ }^{\circ} \mathrm{C}$ throughout the year and water was cycled through a carbon-activated filtration system with an ammonium removing cartridge. The greenhouse was subject to ambient photoperiods, and the temperature inside ranged from $15^{\circ} \mathrm{C}$ to $32^{\circ} \mathrm{C}$ throughout the year with relative humidity between $50 \%$ and $60 \%$. Voucher specimens are deposited at the Orma J. Smith Museum of Natural History, Caldwell, Idaho (Accession numbers ALBRCIDA 00038038-00038051).

We placed two 800 -mL polyethylene beakers ( 1 for each species) in 1 of 3 environmental chambers that controlled for temperature and light. Each beaker was separated from others by cardboard partitions to eliminate behavioral interactions between individuals. Beakers were filled with $500 \mathrm{ml}$ of deionized water, aerated, and left to equilibrate for 2 hours at $20^{\circ} \mathrm{C}$.

Environmental chambers were randomly assigned to a high- or low-temperature treatment or to a control. We assigned one (1) individual of each species randomly to a beaker in an environmental chamber in a classic 2-period, 2-treatment crossover design wherein each individual (except those in controls) would be given treatment $\mathrm{A}$ in period 1, a 24-hour rest period, and then treatment $B$ in period 2. Conversely, another individual (1) of each species 
TABLE 1. Mean high and low activity cessation temperatures $\left({ }^{\circ} \mathrm{C}\right)$ for Valvata utahensis and Pyrgulopsis idahoensis showing no differences between the 3 environmental chambers (EC) used. Standard deviations are given in parentheses.

\begin{tabular}{lccccc}
\hline & EC 1 & EC 2 & EC 3 & $F_{(2,17)}$ & $P$ \\
\hline VALVATA UTAHENSIS & & & & & \\
$\quad$ High & $29.8(4.0)$ & $31.5(3.4)$ & $34.6(2.3)$ & 2.83 & 0.09 \\
Low & $5.86(4.2)$ & $7.58(4.7)$ & $8.43(5.5)$ & 0.42 & 0.67 \\
PYRGULOPSIS IDAHOENSIS & & & & & \\
High & $28.4(2.8)$ & $32.9(2.8)$ & $33.2(3.4)$ & 0.64 & 0.54 \\
Low & $8.5(3.6)$ & $9.5(5.2)$ & $10.0(4.2)$ & 0.15 & 0.85 \\
\hline
\end{tabular}

would be given treatment $\mathrm{B}$, a 24-hour rest period, and then treatment $\mathrm{A}$. This procedure allowed us to double our sample size and test for an effect of the 1st period (treatment A or $\mathrm{B})$ on the response variable of the second period (treatment B or A). Each environmental chamber contained 1 individual of each species for each run. We repeated this crossover design with new snails for a total of 10 replicated runs (i.e., $n=20$ values for upper and lower thermal tolerance for each species) for each treatment and the control (Table 1). In the high treatment, water temperatures were raised by approximately $2.5^{\circ} \mathrm{C} \cdot \mathrm{h}^{-1}$ until the experimental animal exhibited an "escape behavior" (Winterbourne 1969). We defined the escape behavior as an individual retreating deeply into its shell and retracting its operculum. Snails were inspected every hour for escape behavior and water temperatures were recorded. In the low treatment, water temperatures were lowered by approximately $2.4^{\circ} \mathrm{C}$. $\mathrm{h}^{-1}$ until the experimental animal failed to reorient in 3 minutes after being toppled from an upright position. Preliminary "self-righting" tests conducted with both species produced reorientation times of less than $30 \mathrm{~s}(n=30$ for each species). Snails were inspected every hour for the response variable, and water temperatures were recorded. In the control chamber, water temperatures remained constant at approximately $20^{\circ} \mathrm{C}$, and we checked individuals for both response behaviors every hour until the experiment terminated. Average snail size in the test was $4.72 \mathrm{~mm}(3.75-6.0 \mathrm{~mm})$ and $5.07 \mathrm{~mm}(4.0-6.25 \mathrm{~mm})$ for $V$. utahensis and $P$. idahoensis, respectively. All tests took place in darkness, because lights influence temperature inside environmental chambers.

We investigated snail growth rates at 6 temperatures in laboratory experiments to estimate growth rates of snails in the Snake River. We placed twelve $7-\mathrm{L}$ aquaria (6 aquaria for each species) filled with $4 \mathrm{~L}$ of deionized water into 2 environmental chambers assigned to either high- or low-temperature treatments. Each aquarium contained sterilized substrates of silt (V. utahensis) or sand (P. idahoensis) that mimicked substrates at time of collection. Water was aerated and filtered through a carbon filter system. We assessed gastropod growth rates at 6 target temperatures around $20.5^{\circ} \mathrm{C}$, the mean thermal activity range value calculated from above. High-temperature treatments included a targeted $22.5^{\circ} \mathrm{C}, 25.5^{\circ} \mathrm{C}$, and $30.5^{\circ} \mathrm{C}$. The low-temperature treatments included a targeted $18.5^{\circ} \mathrm{C}, 15.5^{\circ} \mathrm{C}$, and $10.5^{\circ} \mathrm{C}$.

The environmental chamber containing the high-temperature treatments was set at $22.5^{\circ} \mathrm{C}$, and 2 aquaria were allowed to equilibrate to this temperature. Heating elements were placed into the other 4 aquaria, and water temperatures were raised to the targeted $25.5^{\circ} \mathrm{C}$ in 2 aquaria and to $30.5^{\circ} \mathrm{C}$ in the remaining 2 aquaria. The environmental chamber containing the low-temperature treatments was set at $10.5^{\circ} \mathrm{C}$, and 2 aquaria were allowed to equilibrate to this temperature. Heating elements were again placed into the remaining 4 aquaria, and water temperatures raised to $15.5^{\circ} \mathrm{C}$ and $18.5^{\circ} \mathrm{C}$.

We randomly assigned 20 small $V$. utahensis $(<2 \mathrm{~mm})$ to each of the 6 temperature groups. We assigned 17, 19, 20, and 16 P. idahoensis to the $25.5^{\circ} \mathrm{C}, 22.5^{\circ} \mathrm{C}, 18.5^{\circ} \mathrm{C}$, and $15.5^{\circ} \mathrm{C}$ groups, respectively (Table 2). Pyrgulopsis idahoensis juveniles, however, were unavailable in sufficient numbers to conduct the $30.5^{\circ} \mathrm{C}$ and $10.5^{\circ} \mathrm{C}$ groups, and only in the $22.5^{\circ} \mathrm{C}$ group were all snails $<2 \mathrm{~mm}$ at the start of the test. The starting size of individuals was important because most organisms show rapid growth of young individuals relative to old individuals, and this variation needed to be controlled by our experimental design. Thus, for P. idahoensis, only our $22.5^{\circ} \mathrm{C}$ group adequately captured the 
TABLE 2. Mean starting and ending shell lengths $(\mathrm{mm})$ for snails in each temperature treatment. Standard deviations are given.

\begin{tabular}{|c|c|c|c|c|c|c|c|c|}
\hline & \multicolumn{6}{|c|}{ Temperature treatment $\left({ }^{\circ} \mathrm{C}\right)$} & \multirow[b]{2}{*}{$F_{(\mathrm{df})}$} & \multirow[b]{2}{*}{$P$} \\
\hline & 10.5 & 15.5 & 18.5 & 22.5 & 25.5 & 30.5 & & \\
\hline \multicolumn{9}{|c|}{ V. UTAHENSIS } \\
\hline Starting & $\begin{array}{c}1.7 \pm 0.39 \\
n=20\end{array}$ & $\begin{array}{c}1.6 \pm 0.30 \\
n=20\end{array}$ & $\begin{array}{c}1.8 \pm 0.28 \\
n=20\end{array}$ & $\begin{array}{c}1.7 \pm 0.42 \\
n=20\end{array}$ & $\begin{array}{c}1.6 \pm 0.21 \\
n=20\end{array}$ & $\begin{aligned} 1.7 & \pm 0.38 \\
n & =20\end{aligned}$ & $1.10_{(5,114)}$ & 0.36 \\
\hline Ending & $\begin{array}{c}3.3 \pm 0.28 \\
n=10\end{array}$ & $\begin{array}{c}3.5 \pm 0.59 \\
n=19\end{array}$ & $\begin{array}{c}3.4 \pm 0.41 \\
n=17\end{array}$ & $\begin{array}{c}3.0 \pm 0.20 \\
n=12\end{array}$ & $\begin{array}{c}3.4 \pm 0.35 \\
n=12\end{array}$ & $\begin{array}{c}1.8 \pm 0.36 \\
n=4\end{array}$ & $12.75_{(5,68)}$ & $<0.0001$ \\
\hline \multicolumn{9}{|c|}{ P. IDAHOENSIS } \\
\hline Starting & & $\begin{aligned} 3.0 & \pm 0.45 \\
n & =16\end{aligned}$ & $\begin{aligned} 3.0 & \pm 0.75 \\
n & =20\end{aligned}$ & $\begin{aligned} 1.9 & \pm 0.41 \\
n & =19\end{aligned}$ & $\begin{aligned} 3.0 & \pm 0.52 \\
n & =17\end{aligned}$ & & $18.69_{(3,68)}$ & $<0.0001$ \\
\hline Ending & & $\begin{array}{c}3.3 \pm 0.28 \\
n=10\end{array}$ & $\begin{array}{c}3.6 \pm 0.50 \\
n=14\end{array}$ & $\begin{array}{c}3.3 \pm 0.37 \\
n=9\end{array}$ & $\begin{array}{c}3.3 \pm 0.82 \\
n=13\end{array}$ & & $1.07_{(3,42)}$ & 0.37 \\
\hline
\end{tabular}

changing rate of growth throughout early snail development. Snails of both species in all temperature groups were removed and measured every 10-14 days to calculate rates of growth. Because snails were small and difficult to locate, we limited our search effort to 30 minutes or $\geq 10$ individuals located, whichever came last. To measure growth for each 10-14-day period, we used a compound microscope with an ocular micrometer to measure the distance (to the nearest $0.01 \mathrm{~mm}$ ) from the apical whorl to the most distal margin of the shell's aperture. Shell lengths in each treatment were averaged for each time period (as individuals could not be identified). Mean shell lengths in each treatment and period were used as variables for growth-rate calculations in the following equation:

$$
\text { Growth Rate }=\frac{\sum\left[\left(\mathrm{L}_{\mathrm{j}}-\mathrm{L}_{\mathrm{i}}\right) / \mathrm{T}_{\mathrm{d}}\right]}{(\mathrm{N}-1)}
$$

where $\mathrm{L}=$ the average shell length at time period $h, i, j, \ldots, n$; $T=$ days between measurements; and $\mathrm{N}=$ total number of measurements/species/treatments.

We inspected each aquarium daily for the presence of egg masses. When eggs were found, snails were removed and measured to the nearest $0.01 \mathrm{~mm}$ to calculate mean size at reproduction. Each week we added approximately $50-100 \mathrm{~mL}$ of cultured freshwater algae in solution (Synedra sp. and Navicula sp., Carolina Biological Supply Co., Burlington, $\mathrm{NC}$ ) to each of the 7-L aquaria as food. We also added pulverized, organically grown eggshell $(0.3-0.5 \mathrm{~g})$ monthly to each aquarium as a source of calcium for shell growth (Voss et al.
2001). The experiment lasted up to 148 days. We did not replace dead individuals, and treatments were discontinued if more than half of the experimental animals died or could not be found.

We recorded water temperatures and conductivity twice daily; and throughout the experiment we periodically measured $\mathrm{pH}$, dissolved oxygen (DO), hardness, and concentrations of ammonium, nitrates, and phosphorus (data provided on request). Throughout the experiment environmental chambers were set to a light-dark cycle of $10 \mathrm{hr}: 14 \mathrm{hr}$, although some researchers have suggested that longer or varying photoperiods may increase growth (Jess and Marks 1998). Water was added as needed to maintain a volume of $4 \mathrm{~L}$ and was changed weekly.

Data from experiments on thermal activity were analyzed using 2-way ANOVA with temperature at time of activity cessation as the dependent variable. Environmental chamber and rate of water temperature change were the independent variables. We used Student's $t$ tests to compare outcomes from the 1st and 2nd periods from both high and low treatments. No data transformations were needed.

Data from experiments on growth rates were analyzed using 3 separate 1-way ANOVAs with growth rate, beginning shell length, and ending shell length as the dependent variables and temperature as the independent variable. We log-transformed growth-rate data to meet assumptions of normality. We conducted post hoc analyses of mean shell lengths using a Tukey's HSD test. Means are presented \pm 1 standard deviation $(s)$ throughout. All statistical analyses were computed with SAS version 8.0 (SAS Institute 2001). 


\section{REsults}

Valvata utahensis ceased activity above $31.7^{\circ} \mathrm{C} \pm 3.4^{\circ} \mathrm{C}(n=20)$ and at temperatures below $7.3^{\circ} \mathrm{C} \pm 4.23^{\circ} \mathrm{C}(n=20)$. Pyrgulopsis idahoensis ceased activity at temperatures above $33.7^{\circ} \mathrm{C} \pm 3.08^{\circ} \mathrm{C}(n=20)$ and at temperatures below $9.2^{\circ} \mathrm{C} \pm 3.7^{\circ} \mathrm{C}(n=20)$. Snails in control treatments did not exhibit either behavioral response during any replicate. Average high and low temperatures in each of the 3 environmental chambers were similar (Table 1). Average rates of water temperature change in the high treatment was $0.40^{\circ} \mathrm{C} \cdot \mathrm{min}^{-1}$ and $0.39^{\circ} \mathrm{C} \cdot \min ^{-1}$ for $V$. utahensis $(n=20)$ and $P$. idahoensis $(n=20)$, respectively. In the low treatment, water temperature change was $0.43^{\circ} \mathrm{C} \cdot \mathrm{min}^{-1}$ and $0.44^{\circ} \mathrm{C} \cdot \mathrm{min}^{-1}$ for $V$. utahensis $(n=20)$ and P. idahoensis $(n=20)$, respectively. Activity cessation values of $V$. utahensis from the 1st and 2nd periods were not different in either high $(t=0.26, \mathrm{df}=18$, $P=0.80)$ or low $(t=0.87, \mathrm{df}=17, P=0.40)$ treatments. Similarly, 1st and 2nd periods from P. idahoensis high $(t=1.22, \mathrm{df}=18, P=0.24)$ and low $(t=1.0$, df $=16, P=0.33)$ treatments were not significantly different. These results collectively suggest that there was no effect of experimental design on activity cessation values for either snail species in our study. Three snails died as result of exposure to high temperature treatments. This explains varying degrees of freedom in the low-treatment results for both $V$. utahensis and P. idahoensis.

Growth rates of V. utahensis and P. idahoensis differed temporally across all temperature groups but could not be compared statistically due to the different experimental designs. However, growth rates from all time periods within a treatment were averaged for an estimate of overall growth rate at that temperature (Fig. 1). Overall growth rates of $V$. utahensis across temperature treatments did not differ $\left(F_{(4,46)}=0.33, P=0.86\right)$. Ending shell lengths of $V$. utahensis differed significantly $(P<0.0001)$ but starting shell lengths were not different (Table 2, Fig. 2). Post hoc analyses revealed that only the $30.5^{\circ} \mathrm{C}$ group differed from other treatments in ending shell lengths, a result which is intuitive as all snails at this temperature died within 2 weeks of the start of the experiment. Across all temperature treatments we observed the highest growth rates of V. utahensis in snails measuring $2.57 \mathrm{~mm}$ on average.

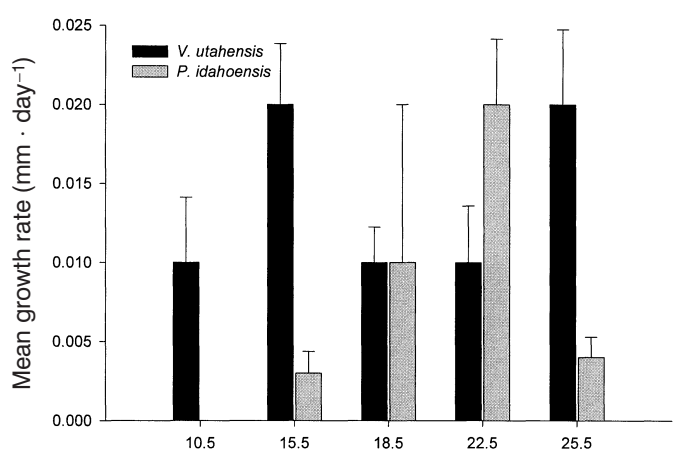

Fig. 1. Growth rates (bars represent 95\% confidence intervals) averaged from all individuals across multiple 10-14-day intervals for Valvata utahensis and Pyrgulopsis idahoensis at different water temperatures $(n=10,10,10$, 9,7 and $n=7,6,8,5$ time intervals, respectively.

Growth-rate comparisons across treatments for P. idahoensis were not conducted (see below). Starting shell lengths were significantly different $(P<0.0001)$ while ending lengths were not (Table 2, Fig. 3). Post hoc analyses showed that the $22.5^{\circ} \mathrm{C}$ group alone differed from all others, a result which is also intuitive as this is the group in which all snails $<2 \mathrm{~mm}$ were placed at the beginning of the experiment. Across all temperature treatments, we observed highest growth rates of $P$. idahoensis in snails measuring $3.09 \mathrm{~mm}$ on average, but this value may be overestimated. No reproduction was observed in either species in any treatment during the 148-day experiment.

\section{Discussion}

We observed a wider thermal tolerance for both species of snails than had been expected and report a reliable method for determining acute activity cessation values. We also found that growth rates and total shell growth did not differ between water temperature treatments for either species; therefore, we reject our hypothesis that cooler temperatures result in higher growth rates. Similarly, evidence failed to support our prediction that growth rates over a range of temperatures would approximate a bell-shaped curve.

We believe our investigation of the thermal activity ranges of both snail species accurately describes their acute physiological tolerance to temperature. For example, the average low 


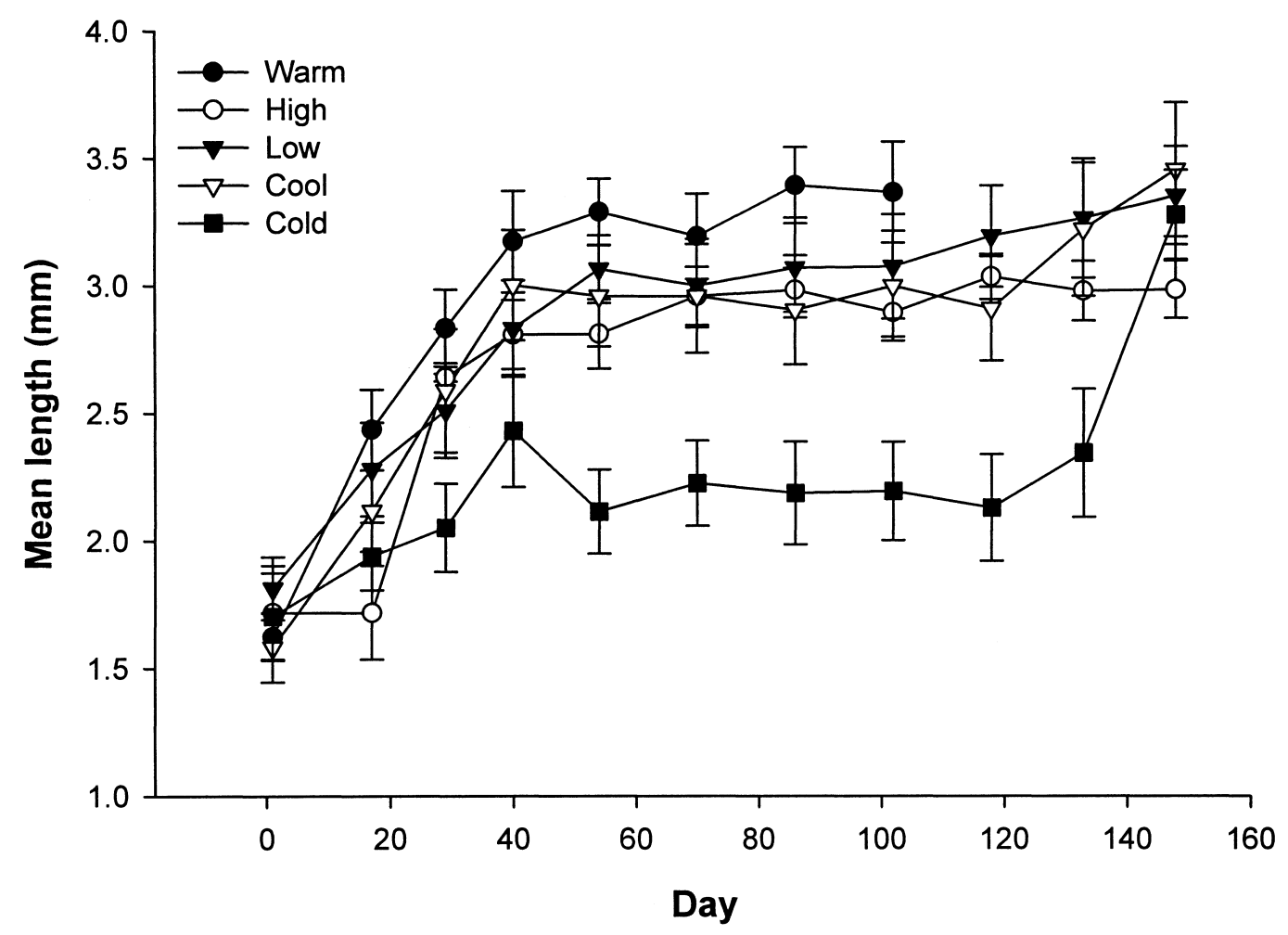

Fig. 2. Mean shell lengths (bars represent 95\% confidence intervals) of Valvata utahensis over time at different temperatures.

temperatures for Valvata utahensis and Pyrgulopsis idahoensis were $7.3^{\circ} \mathrm{C}$ and $9.3^{\circ} \mathrm{C}$, respectively. Temperatures in the Snake River averaged $11.2^{\circ} \mathrm{C}$ and $5.7^{\circ} \mathrm{C}$ in October and November, respectively, about the time snail activity decreases (USBOR 2002). It seems reasonable that, at water temperatures around $10^{\circ} \mathrm{C}$ and perhaps with environmental cues such as changes in daylight, snails will become less active and burrow into the sediments to overwinter. The average high temperatures for both species were outside the range of environmental temperatures found in most temperate freshwaters of North America (Allan 1995) and suggest that both species may tolerate a wider range of environmental temperatures than previously expected. One explanation for our results may be that thermal maxima in freshwater organisms are generally greater when change in water temperature is rapid or acute as opposed to slow or chronic (Quinn et al. 1994). Similarly, Cox and Rutherford (2000) observed an approximate $10 \%$ difference in thermal max- ima with constant versus fluctuating water temperatures. However, our methods (i.e., relatively slow rates of water temperature change) and experimental results were similar to those of other authors studying various invertebrate taxa (Winterbourne 1969, Moulten et al. 1993, Quinn et al. 1994).

There are few studies investigating thermal tolerances of freshwater gastropods from North America to which we can compare our results. Ours are the only known thermal minima reported at which gastropod activity ceases and the only report of thermal maxima from a Snake River species. It is possible that the snails we studied possess a phenotypically plastic response to environmental parameters such as temperature. It is also possible that our results exaggerate the species' thermal activity range. But, is it reasonable that natural selection would favor a eurythermal over a stenothermal temperature tolerance? We believe it is and suggest that without such a plastic response to temperature, particularly for annual species, a single season of extreme temperatures could 


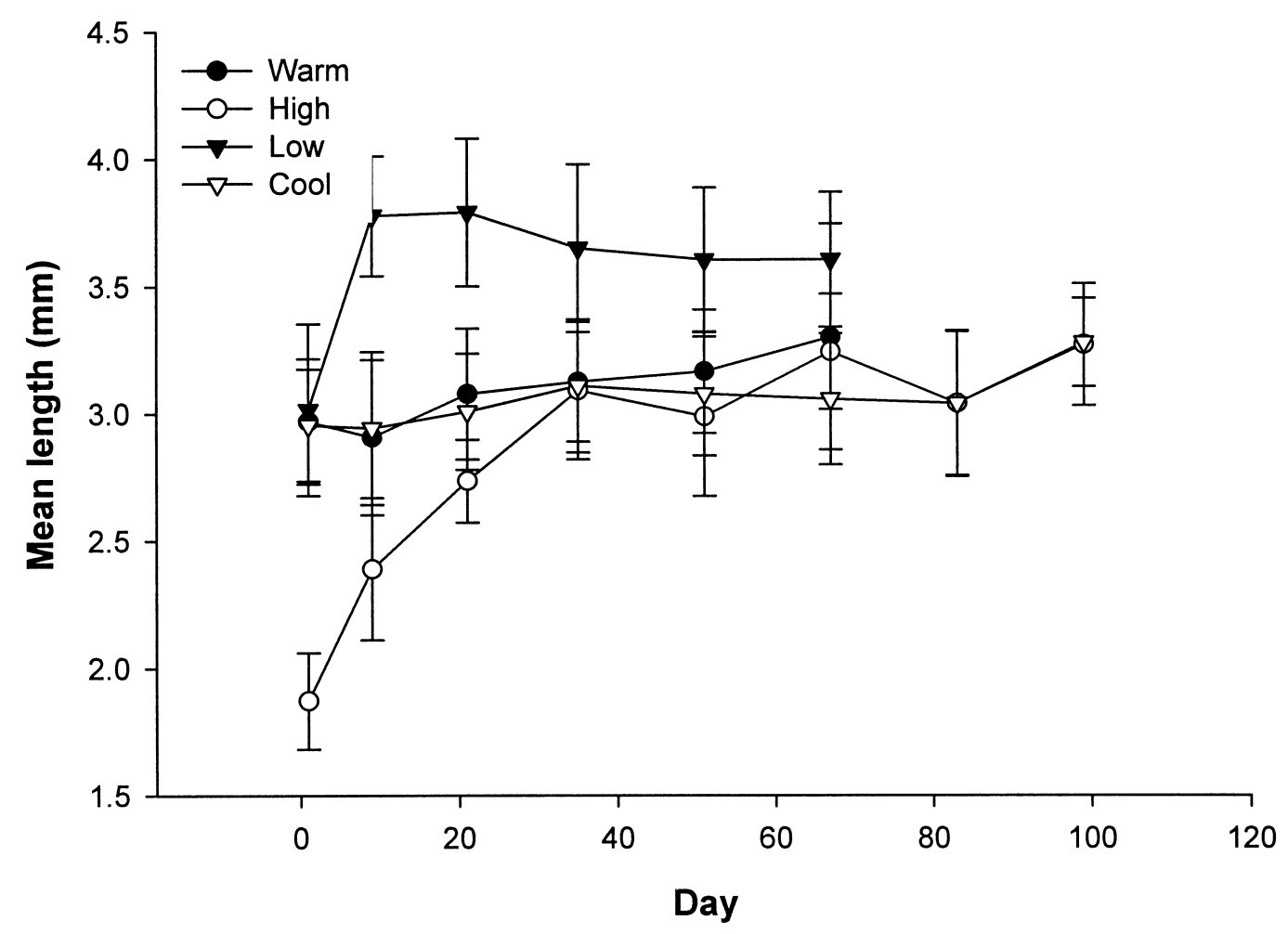

Fig. 3. Mean shell lengths (bars represent 95\% confidence intervals) of Pyrgulopsis idahoensis over time at different temperatures.

result in local extirpations or large scale extinctions.

Although rate of growth and total growth were generally unaffected by temperature in our studies, that information is important. For example, biologists may estimate the age of $V$. utahensis or P. idahoensis using shell lengths and the growth rate information contained herein. Also, we created growth curves for both species which were previously lacking but suggest that those for $P$. idahoensis be repeated with smaller individuals. We were constrained by the number of juvenile $P$. idahoensis $(<2$ $\mathrm{mm}$ ) that could be collected, so we placed all small individuals in a single treatment to capture information about their rapid growth without the variation that would have been introduced by including the relatively slow-growing larger individuals. As a consequence, starting shell lengths in the $25.5^{\circ} \mathrm{C}, 18.5^{\circ} \mathrm{C}$, and $15.5^{\circ} \mathrm{C}$ groups were significantly different than those in the $22.5^{\circ} \mathrm{C}$ group (Fig. 3), and comparison of mean growth rates across temperatures was not possible. Despite this constraint, the growth rate and growth curve from the $P$. idahoensis $22.5^{\circ} \mathrm{C}$ group are likely representative of the species. For example, shell lengths of small $\mathrm{V}$. utahensis across temperatures in this study were not different (Fig. 2). Similarly, shell lengths of P. idahoensis $>3 \mathrm{~mm}$ are not different; therefore, we might conclude that growth rates and shell lengths of smaller P. idahoensis across temperatures are similar to those in the $22.5^{\circ} \mathrm{C}$ group.

Our growth rate experiments lasted a total of 148 days, presumably much shorter than the life span of either species. There was high mortality of snails in most treatments; only the $18.5^{\circ} \mathrm{C}$ and $15.5^{\circ} \mathrm{C}$ treatments for both $V$. utahensis and P. idahoensis had over half of the experimental animals alive at the end of the experiment (Table 2). However, this level of mortality is not uncommon in laboratory studies (Costil 1994). Snails exposed to temperatures of $30.5^{\circ} \mathrm{C}$ died in $<1$ week. Those exposed to lower temperatures of $18.5^{\circ} \mathrm{C}$ and $15.5^{\circ} \mathrm{C}$ 
survived the longest period of time, and those exposed to temperatures of $22.5^{\circ} \mathrm{C}$ and $25.5^{\circ} \mathrm{C}$ grew the fastest.

In summary, we failed to reject our null hypothesis of no difference in growth rate across temperature treatments for $V$. utahensis. However, our prediction of a bell-shaped curve for this species was not observed. This suggests that the previously held view regarding environmental requirements for temperature may be inaccurate (USFWS 1995). While we could not compare growth rates of $P$. idahoensis (see above), our prediction of a bell-shaped curve for that species was supported. Our prediction that cooler temperatures would result in higher growth rates was not upheld, and this too indicates that our previous understanding of the species' temperature requirements may have been inaccurate. Overall, management of the Snake River to meet the temperature criteria of the State of Idaho for cold-water life (i.e., NTE $22^{\circ} \mathrm{C}$ instantaneous, $19^{\circ} \mathrm{C}$ daily average) will be protective of the 2 native gastropod species considered in this work.

\section{ACKNOWLEDGMENTS}

We thank the U.S. Bureau of Reclamation and the U.S. Fish and Wildlife Service for funding. D. Weigel provided field assistance, and R. Hershler provided specimen identification. We also thank Boise State University for support and 3 anonymous reviewers who provided helpful critiques.

\section{Literature Cited}

Albrecht, E.A., N.B. Carreno, and A. Castro-BazQuez. 1999. A quantitative study of environmental factors influencing the seasonal onset of reproductive behaviour in the South American apple-snail Pomacea canaliculata (Gastropoda: Ampullariidae). Journal of Molluscan Studies 65:241-250.

ALLAN J.D. 1995. Stream ecology: structure and function of running waters. Chapman and Hall, London.

Bevelhimer, M.S. 1996. Relative importance of temperature, food, and physical structure to habitat choice by smallmouth bass in laboratory experiments. Transactions of the American Fisheries Society 125:274-283.

BoveE, K.D. 1985. Evaluation of the effects of hydropeaking on aquatic macroinvertebrates using PHABSIM. Pages 236-241 in F.W. Olson, R.G. White, and R.H. Hamre, editors, Proceedings of the Symposium on Small Hydropower and Fisheries, American Fisheries Society Western Division and Bio-Engineering Section, Aurora, CO.

Brusven, M.A. 1984. The distribution and abundance of benthic insects subjected to reservoir release flows in the Clearwater River, Idaho, USA. Pages 167-180 in A. Lillehammer and S.J. Saltveit, editors, Regulated rivers. Engers Boktrykkeri Als, Norway.

CALL, R.E. 1884. On the Quaternary and Recent mollusca of the Great Basin, with descriptions of new forms. U.S. Geological Survey Bulletin 11:1-64.

Christman, S.P., E.L. Mihalcik, and F. Thompson. 1996. Tulotoma magnifica (Conrad 1834) (Gastropoda: Viviparidae) population status and biology in the Coosa River, Alabama. Malacological Review 29:17-63.

Claxton, J.R., J. Sutherst, P. Ortiz, and M.J. Clarkson. 1999. The effect of cyclic temperatures on the growth of Fasciola hepatica and Lymnaea viatrix. Veterinary Journal 157:166-171.

CostiL, K. 1994. Influence of temperature on survival and growth of two freshwater planorbid species, Planorbarius corneus (L.) and Planaorbis planorbis (L.). Journal of Molluscan Studies 60:223-235.

Cox, T.J., AND J.C. RutherFord. 2000. Thermal tolerances of two stream invertebrates exposed to diurnally varying temperature. New Zealand Journal of Marine and Freshwater Research 34:203-208.

Frest, T.J. 2002. Native snails: indicators of ecosystem health. Wild Earth (summer):44-50.

Frest, T.J., AND P.A. Bowler. 1993. A preliminary checklist of the aquatic and terrestrial mollusks of the middle Snake River sub-basin. Proceedings of the Desert Fisheries Council 24:53-58.

Harman, W.N. 1974. Benthic substrates: their effect on fresh-water mollusca. Ecology 53:271-277.

Hershler, R., AND H. LiU. 2004. Taxonomic reappraisal of species assigned to the North American freshwater gastropod subgenus Natricola (Rissooidea: Hydrobiidae). Veliger 47:66-81.

JEss, S., AND R.J. MARKs. 1998. Effect of temperature and photoperiod on growth and reproduction of Helix aspera var maxima. Journal of Agricultural Science 130:367-372.

McMahon, R.F. 1990. Thermal tolerance, evaporative water loss, air-water oxygen consumption and zonation of intertidal prosobranchs: a new synthesis. Hydrobiologia 193:241-260.

Michelson, E.H. 1961. The effects of temperature on growth and reproduction of Australorbis glabratus in the laboratory. American Journal of Hygronomy 73: 66-74.

Moulton, S.R., II, T.L. Beitinger, K.W. Stewart, and R.J. CURRIE. 1993. Upper temperature tolerance of four species of caddisflies (Insecta: Trichoptera). Journal of Freshwater Ecology 8:193-198.

Pilsbry, H.A. 1933. Aminicolidae for Wyoming and Oregon. Nautilus 47:9-12.

Poff, N.L., J.D. Allan, M.B. Bain, J.R. Kark, K.L. PrestegaARD, B.D. Richter, R.E. Sparks, and J.C. StromBERG. 1997. The natural flow regime. BioScience 47: 769-782.

Pringle, C.M., M.C. Freeman, and B.J. Freeman. 2000. Regional effects of hydrologic alterations on riverine macrobiota in the New World: tropical-temperate comparisons. BioScience 50:807-823.

Quinn, J.M., G.L. SteEle, C.W. Hickey, and M.L. Vickers. 1994. Upper thermal tolerances of twelve New Zealand stream invertebrate species. New Zealand Journal of Marine and Freshwater Research 28:391-397.

Richards, D.C., L.D. Cazier, and G.T. Lester. 2001. Spatial distribution of three snail species, including the invader Potamopyrgus antipodarum, in a freshwater 
spring. Western North American Naturalist 61:375380.

SAS Institute. 2001. SAS, version 8.0. SAS Institute, Inc., Cary, NC.

Schrag, S.J., G.T. Ndifon, and A.F. REad. 1994. Temperature-determined outcrossing ability in wild populations of a simultaneous hermaphrodite snail. Ecology 75:2066-2077.

STRZELEC, M. 1999. Effect of artificially elevated water temperature on growth and fecundity of Potamopyrgus antipodarum (Gray) in anthropogenic water bodies in southern Poland (Gastropoda: Prosobranchia: Hydrobiidae). Staaliches Museum für Tierkunde Dresden 19:265-272.

USBOR (U.S. BuREau of REclamation). 2002. Research, monitoring and surveys for snails protected under the Endangered Species Act in the upper Snake River, Idaho. Unpublished report to U.S. Fish and Wildlife Service, Boise, ID. 28 pp.

USEPA (U.S. Environmental Protection Agency). 2002. Final Environmental Impact Statement for hydropower license. Project No. 2055, Federal Energy Regulatory Commission, Office of Environmental and Engineering Review, Washington, DC. 274 pp.

USFR (U.S. Federal Register). 1992. Endangered and threatened wildlife and plants: determinations of endangered or threatened status for five aquatic snails in south central Idaho. Federal Register 57: 59244-59256.

USFWS (U.S. Fish and Wildlife Service). 1995. Snake River aquatic species recovery plan. Region 1, Portland, OR. 92 pp.
USGS (U.S. Geological Survey). 2000. Population monitoring for Valvata utahensis in Lake Walcott, Idaho. Unpublished report to U.S. Fish and Wildlife Service, Boise, ID. 42 pp.

Voss, B., A. Utecht, And W. Wünnenberg. 2001. The dependence of thermopreferendum in Helix pomatia L. on air temperature. Journal of Thermal Biology 26:155-158.

WARD, J.V., AND J.A. STANFORD. 1979. Ecological factors controlling stream zoobenthos with emphasis on thermal modification of regulated streams. Pages 3555 in J.V. Ward and J.A. Stanford, editors, The ecology of regulated streams. Plenum Press, New York.

WATTERS, G.T. 2000. Freshwater mussels and water quality: a review of the effects of hydrologic and instream habitat alterations. Pages 1-14 in Proceedings of the first Freshwater Mollusk Conservation Society Symposium, Ohio Biological Survey, Columbus, $\mathrm{OH}$.

Winterbourne, M.J. 1969. Water temperature as a factor limiting the distribution of Potamopyrgus antipodarum (Gastropoda: Prosobranchia) in the New Zealand thermal region. New Zealand Journal of Marine and Freshwater Research 3:453-458.

. 1970. Population studies on the New Zealand freshwater gastropod, Potamopyrgus antipodarum (Gray). Proceedings of the Malacological Society of London 39:139-149.

Received 8 March 2004 Accepted 2 November 2005 